REGE

25,4

Received 2 January 2018

Revised 16 July 2018

Accepted 25 July 2018

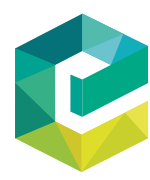

Revista de Gestão Vol. 25 No. 4, 2018 pp. $340-357$ Emerald Publishing Limited 2177-8736 DOI 10.1108/REGE-12-2017-0008

\section{The use of traditional and non-traditional career theories to understand the young's relationship with new technologies}

\author{
Elza Fátima Rosa Veloso \\ FMU, São Paulo, Brazil \\ Leonardo Nelmi Trevisan \\ Pontificia Universidade Catolica de São Paulo, São Paulo, Brazil \\ Rodrigo Cunha da Silva \\ Mestrado profissional, Universidade Anhembi Morumbi, São Paulo, Brazil, and \\ Joel Souza Dutra \\ Administração, Universidade de São Paulo, São Paulo, Brazil
}

\begin{abstract}
Purpose - The purpose of this paper is to, which involved 123 students in their last year of an administration course at a private university in the city of São Paulo, Brazil, evaluate the importance of analyzing the pressure from new technologies on the careers of young university students from a career theory perspective. Design/methodology/approach - From the perspective of traditional theories, the authors used "career anchors," and from the perspective of non-traditional theories, "intelligent careers," in which people develop three competency groups that are transferable between organizations: knowing why; knowing how; and knowing whom. The hypotheses the authors raised were analyzed using statistical techniques and the following results were obtained: young people do not see new technologies as a threat to their current job; people who see the "Knowing How" competence as being more developed feel less pressure from new technologies; non-traditional theories show a greater potential to analyze technological pressure than traditional theories; and, finally, the nature of people's jobs produces different impacts on the pressure of new technologies on their careers, since people who occupy positions involving more human interaction with internal or external clients feel less threatened.

Findings - It was found that the lowest mean among the constructs analyzed was the pressure from technology on career. The correlations between the competencies of intelligent careers and the perception of the pressure from technology on career were weak, but significant, whereas the "Knowing How" competency was negatively correlated with the pressure caused by technology. There was no significant influence of the anchors on the pressure from technology on career. However, incorporating the competencies of intelligent careers improved the statistical model's fit. In associating job positions with the pressure from technology on career, administrative and operational positions showed higher averages than sales associate and management positions.

Originality/value - Broadly speaking, it can be noted that traditional career theories, especially the vocational counseling approach, are not sufficient to explain the impact of new technologies on careers. At the same time, one way of coping with the pressure brought about by technological advances may be in using technology itself to develop "useful professional skills," in a manner consistent with "intelligent careers."
\end{abstract}

Keywords Career anchors, Careers, New technologies, Young professionals, Intelligent careers Paper type Research paper

(C) Elza Fátima Rosa Veloso, Leonardo Nelmi Trevisan, Rodrigo Cunha da Silva and Joel Souza Dutra. Published in Revista de Gestão. Published by Emerald Publishing Limited. This article is published under the Creative Commons Attribution (CC BY 4.0) licence. Anyone may reproduce, distribute, translate and create derivative works of this article (for both commercial and non-commercial purposes), subject to full attribution to the original publication and authors. The full terms of this licence may be seen at http://creativecommons.org/licences/by/4.0/legalcode

Conflict of interest: the authors declare that they are subject to no conflicts of interest. 


\section{Introduction}

The advancement of technologies has led to new thinking about the future of careers. The control that individuals could potentially have over the macroeconomic and institutional forces affecting their job is increasingly smaller. These forces include environmental changes as well as the acceleration of globalization and technological advances (Hall et al., 2018). Technology has been transforming the way people manage both their job and other spheres of life (Haeger and Lingham, 2014). At the same time, Trevisan (2014) states that "the machines of the Information Technology (IT) age increasingly occupy the space of humans" (p. 94).

The evident gap in the recent international literature, made explicit by Barley et al. (2017), makes it clear that we need to study the association between the theme of careers and technology. These authors explain that the nature of employment has been changing in the last four decades and will continue to change in the 21st century, but they were surprised by the lack of attention to this phenomenon in the studies. In the view of Barley et al. (2017), it is even difficult to know whether technologies change the nature of work, by creating more flexible jobs and organizations, or if, on the contrary, organizations transform and change the way people work. These authors suspect that both phenomena occur simultaneously.

Based on these observations, we see the importance of analyzing the pressure from new technologies on the careers of young university students from a career theory perspective; and so this was the goal of the study presented in this paper, which involved 123 students in their last year of an Administration course at a private university in the city of São Paulo, Brazil. The relevance of the sample selected for this survey lies in the fact mentioned by Haeger and Lingham (2014) that various generations coexist in the work environment and youth are more experienced with technology, thereby affecting the older generations.

To achieve the goals of this study, we considered the perspective of Arthur et al. (1999), who suggest dividing career theories between traditional and non-traditional. According to these authors, while traditional theories focus on the connection between career and personal fulfillment by considering a career as "the series of jobs worked by a person throughout their life" (p. 3), non-traditional theories emphasize "self-organization of one's career," which now needs to adapt to the environment (p. 10).

Below, we present the theoretical framework underpinning our field research. In the same topic, we also present the hypotheses that guided our work. Our methods are explained in the subsequent item, followed by our results, our discussion thereof, and our conclusions.

\section{Theoretical framework}

To reflect on the topic of careers, it is important to note the statement from Hall (1986) that the scientific field dealing with this subject is both theoretical and practical. Arthur et al. (1999) emphasize that the perspective of time is valued in career theories, something that does not occur with other approaches toward work. Therefore, experiences and discoveries are important for these theories, and careers involve a series of steps that precede and influence them. For these authors, career theories are very important and can be divided into traditional theories and non-traditional theories. In Brazil, Veloso (2009, 2012) dealt with the evolution of career theories and addressed this division, which is dealt within detail below.

\subsection{Traditional career theories}

After the Second World War, according to Arthur et al. (1999), large companies' investments in career paths were focused on the need to obtain loyalty from their employees. At that time, human resource managers sought to allow companies to achieve their goals by cultivating a stable workforce. This is the environment of organizational careers, which are careers
Traditional and non-traditional career theories 
REGE

25,4

342

designed to reveal a single employment scenario (Arthur and Rousseau, 1996). The first career theories were created in this environment and were aimed toward Industrial Society.

Veloso $(2009,2012)$ highlights the fact that, according to Arthur et al. (1989), in the early 1970s, the conceptual bases for dealing with this subject were provided by vocational psychology and sociology. At this time, the major interest was in associating career cases with jobs in organizations.

Hall (1986) states that, until the 1980s, theoretical, research and practical work in the field of careers was focused on human resource planning. At that time, "nontraditional career movements," which involved lateral transfers, temporary contracts, transferring to non-management positions, and moving down the corporate hierarchy were all viewed as exceptions by organizations. This same author (Hall, 1996) explains that people were seldom concerned with pursuing their own professional paths and turned instead to common expectations focused on survival.

This traditional way of analyzing careers, according to Arthur et al. (1999), is represented by traditional theories, which do not consider the reciprocal effects between career episodes or between one's career and the environment - which, in this case, comprises the profit-making institutions with which an individual interacts. These authors present three approaches that are representative of this theoretical vision: developmental theories, the human resource management approach, and the vocational counseling approach.

With regard to developmental theories, Arthur et al. (1999) refer to Dalton and Thompson (1977) and explain that, in this approach, a career is made up of steps of ascension, and that this is one of the phases in the formation of a person's identity, the development of competencies, and the construction of relationships and leadership. In the human resources management approach, the use of individual talents is essential in the development of careers - career systems are planned out with several hierarchical levels, usually in paternalistic companies. At the same time, in the vocational counseling approach, the search for the "right person" for each job requires the use of vocational tests. These authors affirm that, in both the vocational guidance and the human resources management approaches, ideas about human potential are associated with inert subjects, whose development is influenced by corporate interests. They explain that one variation of the vocational counseling approach is Schein's (1978) career anchors, where prior professional experience allows the anchors guiding an individual's professional life to be identified.

Traditional theories are representative of organizational careers, which in turn reflect a time when, according to Arthur (2014), the ideal was to obtain a job a keep it for life. In addition to the reflections by Van Maanen (1977), who understands this type of career as those taken to evolve over time in the same organizational environment, Arthur highlights the definition by Schein (1978), who considered organizational careers as interactions between individuals and organizations over time, in a mutually profitable relationship. In Arthur's (2014) explanation, it is possible to understand the logic in the use of developmental theories and the human resources approach, highlighted by Arthur et al. (1999) in the study of careers, because when jobs were stable, organizations needed to plan their career system while considering the development of the people in the organizational environment.

Arthur (2014) explains that, in the context of organizational careers, career studies served as a natural extension of the field of organizational behavior, with lifelong jobs idealized across the board. In parallel, to explain traditional theories, Arthur et al. (1999) emphasizes the fact that the vocational counseling approach adopts factorial theories based on human typologies, which assume that a person's characteristics are stable throughout life. This allows people to be analyzed based on their initial professional experiences, and these analyses, in turn, highlight career anchors, which would determine their professional lives. 
To elaborate on the concept of "career anchors," Schein (1990) conducted studies, beginning in the 1960s, in which he interviewed Master's students from the MIT Sloan School of Management. Further interviews were later held with the same participants after they completed the course. The purpose of the analyses was to understand the evolution of the careers and values present in professional activities.

Under the perspective of the anchors, a metaphor that elicits the notion of comfort and adjustment, individuals would return to professional practices that were consistent with their self-image when faced with occupations that were at odds with their goals and attitudes. In Schein's studies, an individual's professional inclination is so significant that it is not abandoned, even in a crisis situation. The anchors described by Schein (1996) are as follows.

Technical/functional competence (TFC). People with this anchor feel professionally fulfilled when facing technical challenges. They avoid managing others when it requires them to move away from their specialty.

General managerial competence (GMC). People with this anchor feel professionally fulfilled when they are responsible for results and identify their own work with the success of the organization.

Autonomy/independence (AI). People with this anchor are not very tolerant of rules established by other people or by the organization itself. These various forms of control are rejected and the professional seeks out roles that allow for flexibility.

Security/stability (SS). People with this anchor find the content of the work to be less important than their concern for guaranteed employment and the feeling of tranquility derived from professional stability.

Entrepreneurial creativity (EC). People with this anchor strive to create their own organization, products or services, taking risks and always seeking future opportunities.

Service/dedication to a cause (SDC). People with this anchor seek occupations in which they feel that they accomplish something useful - for example, by helping others, improving the harmony between people, or solving environmental problems.

Pure challenge (PC). People with this anchor are drawn to solving problems that seem unsolvable, overcoming difficult obstacles, and surpassing opponents. They also seek out interpersonal competitions.

Lifestyle (LS). People with this anchor consider it essential to find a balance between their personal, professional, and family needs. They seek sufficient flexibility to integrate every element of their lives.

The relevance of using career anchors as a variation of traditional theories, in the context of analyzing technological advances associated with careers, is reinforced by the reflections of Bravo et al. (2015). These authors explain that anchors were developed more than 40 years ago, when careers were more stable, so the original construct may exhibit certain outdated assumptions, but because of their focus on internal values and needs, they remain useful when analyzing important factors behind career choices, in a more current view.

Based on these reflections by Bravo et al. (2015), it was possible to consider, in this study, the possibility of working with career anchors as being representative of traditional career theories, without losing relevance with regard to the new work contexts that are permeated by the growing advance of technology.

\subsection{Non-traditional career theories}

According to the approach by Veloso (2009, 2012), Hall (1996) explains that, starting in the 1990s, resource scarcity and changes in society and organizational cultures meant that people did not have or did not want to have long-term expectations for their jobs. In this process, according to Hall, the focus of studies turns to the meaning and purpose of work, to identity and learning. 
REGE 25,4
In the 2000s, according to Hall (2002), people started to work more independently, and the theoretical focus turned to the loss of boundaries between careers, because the movement between organizations became not only natural, but essential. In this context, we saw the development of non-traditional theories, described by Arthur et al. (1999), which focus on the New Economy and provide the conceptual support currently required for the study of careers: the Chicago school; psychology; and social sciences.

To explain the Chicago school, these authors turn to Barley (1989). In this perspective, the focus of studies is diverted from the bureaucratic structures of organizations and their positions to more dynamic and flexible situations and to spaces of individual, social, and family life. From the perspective of psychology, they turn to Bell and Staw (1989) to describe people as shapers of their own careers and creators of personal meaning in their work.

The perspective of the social sciences, according to Arthur et al. (1999), emphasizes the importance of seeing a career as a system, with interdependent elements that adapt to its environment, rather than the cause and effect relations in a person's career.

According to Veloso $(2009,2012)$, the protean career and boundaryless career theories are two ways of making sense of the social and organizational changes that have led to the need for professionals to manage their own careers. At the same time, Kostal and Wiernik (2017) state that these conceptions have dominated the theoretical landscape in the last two decades, and are currently referred to as "the new career," a concept that arises from a globalized economy and that comprises a significant change in the psychological contracts between employees and companies.

The boundaryless career is cited by Arthur et al. (1999) as a counterpoint to traditional theories. According to Hall (2002), the protean career allows us to study careers in the New Economy, where non-traditional theories have begun to make sense, in a scenario in which security, in both hierarchical and social terms, is increasingly lower.

The protean career represents the process in which the person, not the organization, is managed. This type of career has psychological success as its main impulse (Hall, 1996, 2002). Hall et al. (2018) recall that, in the 1970s, Hall (1976) described this type of career as an orientation that allows people to promote social, political, technological and economic changes in various cycles of their professional lives.

Boundaryless careers are careers that transcend organizational boundaries and in which career mobility is supported by professional networks, labor market information, and the voluntary search for new knowledge (Arthur and Rousseau, 1996). Arthur (2014) listed various contributions and six meanings for this type of career: it reflects movements across the boundaries between different employers; it is designed to be valid beyond a single employer; it is supported by external networks or information; it breaks the traditional relationships of subordination and hierarchy; career opportunities can be rejected for family reasons; a future without boundaries is perceived independently of structural constraints.

Gunz et al. (2000) explain the hypothesis of boundaryless and intelligent careers, which is a model based on competencies compatible with the knowledge economy, sparked by waves of downsizing that hit economies in the 1990s and helped people find themselves in the face of a threatening world devoid of security.

Khapova et al. (2007) explain that the first proposal for intelligent careers derives from the work of Quinn (1992) on intelligent enterprises, in which knowledge guides the organization, which needs to develop skills related to culture, know-how, and networking. In a world without borders, people need to develop skills that are transferable between organizations.

For people, Arthur et al. (1995) propose the accumulation of competencies that should not be subordinated to employers. Veloso $(2009,2012)$ pointed out the competencies proposed by these authors:

- Knowing why: reflects individual identity and motivation, personal meaning, and identification with one's job. 
- Knowing how: represents the individual abilities and specialties relevant to the job. Traditional and

- Knowing whom: reflects the interpersonal relationships and networks that are important for the work. non-traditional
career theories

In the analysis of intelligent careers, Arthur et al. (1999) emphasize the value of job training and life experience in obtaining these competencies, which should be considered a form of career capital, which can gain or lose value, depending on the person's investment. In the current context, we consider that technology can permeate the construction of the competences supporting intelligent careers; this is the subject addressed below.

\subsection{Career and technology}

The current work environment is permeated by changes that increasingly make career planning difficult for both individuals and businesses. Guan et al. (2017) explain that the increasingly globalized economy, rapid technological advancement and changes in organizational structures have resulted in changes in employment relationships, which have become more flexible, leading to career patterns that are less predictable.

In the Brazilian workplace, it is possible to perceive the role played by new online businesses as a kind of threat to traditional jobs in different industries. Thinking about this scenario requires us to understand that various occupations are compelled to compete not only with production automation, but with the actual occupation of production structures by IT that is increasingly capable of replacing any professional performance. This IT expansion knows no limits, especially not educational ones: a college or university degree no longer represents significant or effective protection against replacement of a human occupation by an "electronic reality" (Trevisan, 2014).

The risk of this process of replacement for human activities is real and can even be measured over time. A study conducted at Oxford University discussed "speed and motive" for machines to replace human occupations (Frey and Osborne, 2013). The focus of this study was to investigate which tasks were more or less threatened by technological evolution. Basically, what Frey and Osborne wanted in this study was to explain the degree of "standardization" that allowed software engineering to replace, with greater or lesser ease, different types of occupation. The Oxford study showed that 47 percent of human tasks could undergo "automated replacement" within a period of up to ten years, based on the technological evolution known in 2012, and the degree of standardization required in each human task.

The central point of this investigation, therefore, was to understand what could be called the evolutionary history of standardization. The scope of this "evolution" is that it allows technological mobility to occur in the search for applications of leading-edge technology that benefit the careers of some and define the stagnation of the careers of others. The question of the history of automation was defined by researchers at the Massachusetts Institute of Technology (MIT) who linked standardization with routine to understand human tasks that could be replaced by machines (Autor and Price, 2013).

In this study, routines were separated into two levels. The first considered routine cognitive occupations, that is, everything that pertained to classifying or coding - typical tasks for almost every office or service provider. The second level referred to the manual routines found in every "production line," whatever the activity. In this view, the activities threatened by machines were limited to routine manual activities, which were easier to be replaced by robotics. Cognitive routines, in the view of Autor and Price, which required creativity, intuition, and persuasion, would be far less threatened by automation. In this process, technological mobility, in the sense of career mobility imposed by technology, made sense as a result of the distance gained from manual routines. 
REGE 25,4
However, the protection of "non-routine" tasks for automation was also overcome, as evidenced by Frey and Osborne (2013). According to their research, jobs that require problem solving, or a flexible analysis of reality, or even the resolution of conflicts between parties, are no longer safe from the advances of automation. The crux of the Oxford study is its method, a significant advance in the evolution of standardization. Frey and Osborne focused their work on another format of the nature of human occupation, searching for algorithms that would make the standardization required in human tasks more flexible, i.e., automation could also do jobs that required diverse problem solving.

The origin of the qualitative leap in the evolution of standardization is owed to big data, that is, the possibility that software has gained to accumulate large volumes of data, surpassing the order of billions. With the use of big data, occupations that previously required decision-making ability, that is, the evaluation of possibilities to arrive at a choice became standardizable. In other words, when a machine has the avalanche of information that big data allows, it is able to identify the best solution to accomplish that task, from among several, and repeat the decision-making process whenever it is requested. The understanding of the automatic implementation of tasks that require choices, for example, of driving a car without a human driver, passes through this leap in standardization: the accumulated data for each street, stop light times, and the unexpected presence of other objects allows the software to make a decision between accelerating, slowing down, or stopping the car. We should not forget that big data is also the solution that provides the route to be taken by nonhuman drivers (Trevisan, 2014).

What the research by Frey and Osborne (2013) showed is that other routine cognitive tasks (flexible and decisive, but repetitive) that, in the past, only humans could perform, could be automated without risk. In different industries: drafting a contract, reading a medical chart, or the process of selecting people fit for a certain occupation could be as automated as the task of driving a car without human intervention. The method of standardizing the cognitive routine required by these different tasks was the same.

With the realization that the "nature" of standardizable human tasks had evolved with big data, Frey and Osborne (2013) identified and cataloged the standardizable tasks, both cognitive and manual, of each occupation cataloged by the US Department of Labor, which in practice makes up a considerable part of the list of human tasks. This correlation carried out by the Oxford researchers showed that, of the 903 occupations listed, 702 were susceptible to standardization, at different speeds. Based on this correlation between already-listed human tasks and the standardization capability of robotics, the Oxford researchers identified that 47 percent of the 903 occupations would be replaced in various ways by different phases of automation, via software or robotics processes.

The central question posed in the research paper presented in this paper is the ability of young professionals to perceive this process of continuous automation of standardizable tasks. Callanan et al. (2017) explain that technology is an environmental factor to be predicted and accounted for in career planning. These authors recognize the double meaning of the role of artificial intelligence and technology itself in the present context, because, as they destroy industries and jobs, they create opportunities for new ventures and new career possibilities.

As researchers from Carnegie Mellon University reported, in the early stages of the automation process, even IT professionals swayed in their perception, not just accepting the evolution of their careers in the more traditional format, but also seeking a more "boundaryless" profile, because they did not clearly identify the constant cycles of automation (Boh et al., 2001). Therefore, different ways of thinking about career mobility are significantly correlated with the perception of automation advances.

Based on the theoretical framework presented here, we elaborated this study's hypotheses, which guided the construction of the methods that defined the field research 
and our analysis of our results. These hypotheses are described below, with references to the main reflections that led to their elaboration.

First hypothesis. There is no limit to the expansion of information technology, and a university diploma no longer protects against the increasing possibility of replacing jobs previously performed by people with machines (Trevisan, 2014). Given this context, the young graduates of the management course are probably concerned about the impact of technology on their careers. From this reasoning, we formulated this study's first hypothesis:

H1. Young professionals are concerned about their careers due to the incorporation of new technologies in the organizational context.

Second hypothesis. Intelligent careers, which stem from the decline in jobs that occurred in the 1990s, consist of a competency-based model that is appropriate to the Knowledge Economy and seeks to help people cope with an unsafe and threatening world (Gunz et al., 2000). Since there is currently a new wave of insecurity caused by technological advances (Trevisan et al., 2016), it is possible to assume that technologies themselves drive people to develop intelligent careers by consolidating competencies that are valuable in job market. This reasoning generated the following hypothesis:

H2. There is a positive relationship between the perception of the competencies of intelligent careers and the pressure of new technologies on careers.

Third hypothesis. Traditional theories were developed in a stable environment and do not consider the need for individuals to react to the different economic and social contexts that involve work (Arthur et al., 1999). Non-traditional theories were constructed in response to an unstable environment, where the focus of the studies turned to the need for movement between organizations to become natural and essential (Hall, 2002). Thus, in view of the need for young graduates to move their careers and learn to deal with the increasingly technological context, it is possible to infer that non-traditional theories are more appropriate when analyzing the pressures that new technologies exert on these people. This reasoning generated the following hypothesis:

H3. The pressures of new technologies on careers are more easily analyzed through non-traditional career theories than traditional ones.

Fourth hypothesis. The nature of human tasks is associated by Frey and Osborne (2013) with the possibility of standardizing work. These authors showed that the most standardizable tasks would be more quickly replaced by automation via software or robotic processes. In this way, it is possible to assume that the respondents would show differences in their perception of the pressure of new technologies depending on the nature of the work they perform:

H4. The pressure of the new technologies on the career shows differences depending on the nature of the work that the person performs.

After presenting the conceptual aspects of our work and our hypotheses, we present below the methodology supporting our field study.

\section{Methodology}

The survey was carried out between November and December 2016, by means of two printed questionnaires, applied in person by the researchers, during class time. These questionnaires were handled quantitatively and were answered by 123 students of the administration course in a private university in the city of São Paulo. Any missing data were replaced by the average answer for the respective question. This procedure was adopted
Traditional and non-traditional career theories 
REGE 25,4

\section{8}

because missing cases did not exceed 5 percent of total valid answers. It is important to note that outliers have also been verified.

According to the general goal of the study, which is to analyze the pressure of new technologies on the careers of young university students from the perspective of career theories, the following reasoning guided our choice of research instruments.

New technology patterns generally result in new forms of work, which also affect other spheres of people's lives (Haeger and Lingham, 2014). To evaluate the pressures caused by these new patterns from the standpoint of traditional theories, we used career anchors (Schein, 1990). Thus, the first questionnaire we applied was that developed by Schein (1990, 1996), on a six-point Likert scale.

Next, the assessment of these same pressures from the perspective of non-traditional theories was based on intelligent careers, in which people develop three groups of competencies that are transferable across organizations: knowing why; knowing how; and knowing whom (Arthur et al., 1995). The content of the assertions was based on an adaptation of the instrument by Veloso et al. (2012), which operationalized the concept of intelligent careers in a scale that was published and made available to Brazilian researchers (Arthur et al., 1995).

At the same time, considering the new standardizations of jobs and the pressures regarding the possibility that their tasks could be replaced by technology, questions were developed based on the reflections by Trevisan (2014), using an adaptation of the scale published in Trevisan et al. (2016). Thus, after the career anchor inventory, a second questionnaire, adapted by the authors, was applied based on the indicators shown in Table I. This table lists the associations resulting from the theory with the indicators adopted in the questionnaire, all in a five-point Likert scale. The descriptions of the assertions are found in Table IV, in the section containing our results and discussion thereof.

It is important to clarify that the career anchor variable was treated as a continuous variable. An overall score was used to generate an explanatory variable for the analyzed model. Thus, there was no impact to the regression model from differences in Likert scales, since the variables were transformed into the same numerical basis.

In order to ascertain the relevance of the proposed instrument, the assertions elaborated to measure intelligent careers were submitted to the technique of exploratory factor analysis (EFA). There are two types of factorial analysis: exploratory and confirmatory (CFA). In general, the EFA is used in the more embryonic stages of research, to explore the data. In this phase, researchers seek to explore the relationship between a set of variables and identify patterns of correlations. In addition, the Cronbach's $\alpha$ score was calculated to

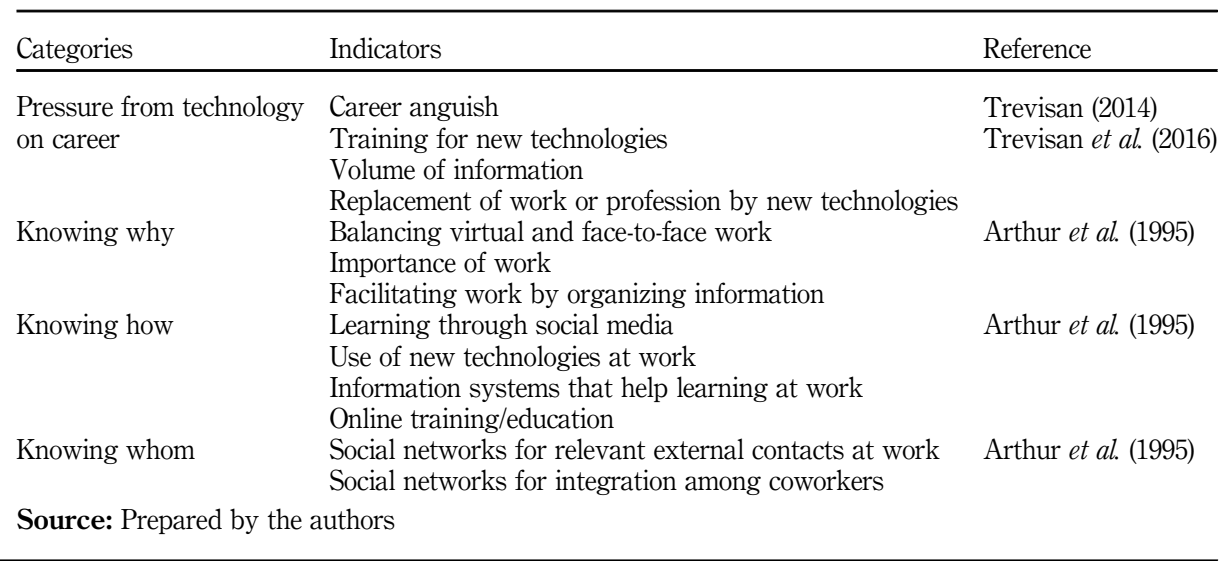

\section{Table I.}

Relationship between questionnaire indicators and categories
Source: Prepared by the authors 
ascertain the reliability of the measurement instrument and its factors, based on its internal consistency. In other words, we tried to verify that the variables that propose to measure these factors produce similar results (Hair et al., 2009).

To test this study's hypotheses, we adopted multiple regression analysis, which aims to project a dependent variable as a function of independent variables. The dependent variable studied here is "the pressure of new technologies on the career" and the independent variables are: career anchor, intelligent career competencies, and respondent profile. Then, using analysis of variance (ANOVA), we sought to compare the impact of differences in means based on respondent profile. The results are shown in the following section.

\section{Results and analysis}

To read the results, it is important to highlight the fact that the use of the career anchor instrument as a representation of traditional theories does not entail the practice of organizational careers by individuals. Similarly, the use of questions about technology and intelligent careers does not represent "adoption of new careers." As Kostal and Wiernik (2017) explain, the concepts of boundaryless careers and protean careers, despite dominating recent research, only represent "new career orientations," which differ between the various demographic groups.

In this study, the mean age of respondents was 23 years, with less than 2 years at their current company. In all, 61 percent were men, 39 percent were women. 90 percent were employed. 50 percent worked in administrative positions, and 70 percent in the service sector. When asked about the department in which they would like to work, roughly 35 percent answered that it would be in marketing, 30 percent in finance, 25 percent in human resources and 20 percent in "other departments."

\subsection{Analysis of career anchors}

Table II shows the means and standard deviations of the respondents' career anchors.

The highest mean was in the lifestyle anchor (4.83) and the lowest was in the service and dedication to a cause anchor (3.72). These results have been repeating in several studies about career anchors, as in Gomes et al. (2013), Veloso et al. (2014), Trevisan et al. (2016), Silva et al. (2016).

Next, in Table III, we present the correlations between the anchors and the construct of the pressure of technology on career.

In analyzing the correlations, it was found that none were significant at the $p<0.05$ significance level. This result may indicate, initially, that the traditional theories represented in this study by career anchors are unable to explain alone which groups of people would best deal with the introduction of new technologies to the world of work or which would somehow feel threatened by them.

\begin{tabular}{lcr}
\hline Career anchor & Average & SD \\
\hline TFC & 4.08 & 0.84 \\
GMC & 3.87 & 1.10 \\
AI & 4.48 & 1.28 \\
SS & 3.72 & 1.08 \\
EC & 4.09 & 1.40 \\
SD & 4.17 & 1.04 \\
PC & 4.36 & 1.30 \\
LS & 4.83 & 1.28
\end{tabular}

Source: Prepared by the authors

\section{Traditional and non-traditional career theories}

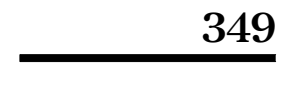


REGE 25,4

\subsection{Analysis of intelligent careers and technologies}

The second questionnaire was developed considering the relationship between the competences of intelligent careers with the emergence of new technologies and their pressure on career. The averages and standard deviations of the assertions, grouped by type of competency, are shown in Table IV.

\section{0}

Career anchors

Pressure from technology

$\begin{array}{lr}\text { TFC } & 0.05 \\ \text { GMC } & -0.06 \\ \text { AI } & -0.07 \\ \text { SS } & 0.18 \\ \text { EC } & 0.05 \\ \text { SD } & 0.07 \\ \text { PC } & -0.15 \\ \text { LS } & 0.03\end{array}$

Table III.

Correlations between

anchors and the pressure of new

technologies on career Source: Prepared by the authors

0.05

$-0.07$

0.18

0.05

$-0.15$

0.03

\begin{tabular}{|c|c|c|c|}
\hline & & $M$ & $\mathrm{PC}$ \\
\hline code & Pressure from technology on career & 2.06 & 0.86 \\
\hline tec1 & $\begin{array}{l}\text { The introduction of new technologies in my profession makes me anguished about the } \\
\text { future of my career }\end{array}$ & 1.76 & 1.13 \\
\hline tec2 & $\begin{array}{l}\text { I feel pressured by the need for constant training to use new technologies to work } \\
\text { in my profession }\end{array}$ & 2.80 & 1.32 \\
\hline tec3 & I feel uncomfortable with the high volume of information from computer programs that & 236 & 133 \\
\hline tec4 & I am afraid that my job will be replaced by machines or computers & 1.81 & 1.15 \\
\hline tec5 & $\begin{array}{l}\text { I believe that my profession may cease to exist because of technological advances } \\
\text { Knowing why }\end{array}$ & $\begin{array}{l}1.57 \\
3.26\end{array}$ & $\begin{array}{l}0.98 \\
0.79\end{array}$ \\
\hline why1 & When I can use social media at work, I feel more accomplished professionally & 2.72 & 1.33 \\
\hline why2 & $\begin{array}{l}\text { I believe that the balance between online and face-to-face professional activities that I } \\
\text { carry out is appropriate for my needs }\end{array}$ & 3.56 & 1.15 \\
\hline why3 & I feel that my job is important for my profession's technological evolution & 3.11 & 1.29 \\
\hline why4 & $\begin{array}{l}\text { The use of information organized by computer programs helps me understand } \\
\text { the meaning of my professional activities }\end{array}$ & 3.65 & 1.17 \\
\hline & Knowing How & 3.81 & 0.78 \\
\hline how1 & Using social media helps me learn new things associated with my job & 3.22 & 1.42 \\
\hline how2 & Using computer programs gives me the information I need to do my job well & 4.32 & 0.98 \\
\hline how3 & $\begin{array}{l}\text { In my profession, I am encouraged to contribute to improving the way I use } \\
\text { technologies important to my job }\end{array}$ & 3.82 & 1.17 \\
\hline how4 & Computer programs encourage me to seek new professional knowledge online & 3.85 & 1.25 \\
\hline how5 & $\begin{array}{l}\text { Access to information organized by computer programs helps me decide what to do to } \\
\text { learn more professionally }\end{array}$ & 3.85 & 1.05 \\
\hline how6 & $\begin{array}{l}\text { At my job, I have the opportunity to participate in online training activities } \\
\text { Knowing Whom }\end{array}$ & $\begin{array}{l}3.80 \\
3.65\end{array}$ & $\begin{array}{l}1.35 \\
0.86\end{array}$ \\
\hline whom1 & Social media helps me meet people important to my professional growth & 3.44 & 1.33 \\
\hline whom2 & Online professional networks make it easier to interact with my colleagues & 3.76 & 1.14 \\
\hline whom3 & My colleagues are always willing to help each other online & 3.49 & 1.21 \\
\hline whom4 & $\begin{array}{l}\text { Using computer programs helps me keep in touch with people who can drive } \\
\text { me to grow in my career }\end{array}$ & 3.92 & 1.07 \\
\hline re & Prepared by the authors & & \\
\hline
\end{tabular}

Table IV.

Means and standard deviations about new technologies and impact on career 
After analyzing the results shown in Table IV, we found that the highest average was for the "Knowing How" construct (3.81) and the lowest for "pressure of technology on career" (2.06). From these results, it can be assumed that, for the respondents, the pressure of the new technologies on career is not a high concern at the time of the study, which refutes $H 1$, that young professionals are worried about their careers due to the introduction of new technologies in the context of their organization.

The result related to technologies is consistent with the study presented in Trevisan $e t$ al. (2016) and also with Alves (2016). In these authors' results, respondents were also not worried about the possibility of their jobs being replaced by new technologies. On the other hand, the results regarding "Knowing How" are probably related with the respondents' investment in their education, which corresponds to the recommendation of Arthur et al. (1999) in his proposal about new careers.

After the analyses, the questionnaire's assertions underwent exploratory factorial analysis, in order to analyze the pertinence of the theoretical reference that served as the foundation for this study's instrument. Table V shows the moderate and significant values $(p>0.01)$ of correlations found in the relationships between the "Knowing How" and "Knowing Why" and "Knowing Whom" and "Knowing How" constructs. There were weak but significant correlations $(p>0.05)$ between "Knowing How" and "Knowing Whom" and "Knowing How," beyond the pressure from technology.

The perception of Knowing How has been negatively correlated with pressure from technology, indicating that the higher the perception of the development of this competence of intelligent careers, the lower the perception of the pressure from technology on the career. This result partially confirms $H 2$, that there is a positive relation between the perception of the competencies of intelligent careers and the pressure of new technologies. In interpreting this data, it is also possible to note the lower perceived threat from new technologies for people who develop more of their work-relevant skills, which corroborates Arthur et al. (1995). This finding establishes the development of these skills as a kind of job protection in the perception of the respondents.

In the reliability analysis, shown in Table $\mathrm{V}$, four of the five constructs have satisfactory Cronbach's Alpha reliability scores (above 0.7); however, the value for the "Knowing Why" construct was approximate but lower than the reference value. Such a result indicates satisfactory reliability and replicability of the instrument's responses to a greater number of respondents. However, the unfavorable outcome of "Knowing Why" may be due to varying interpretations of this construct in the respondents' perception, and may require changes to the research instrument.

The quality measures of the exploratory factor analyses KMO (0.70), MSAs ( $>0.5)$, and the Bartlett test $(p<0.01)$ were satisfactory. In addition, the combined explained variance of the three factors was 54.02. The factors were extracted through the principal axis method, with varimax rotation, fixed at four constructs, based on the theory of the competencies of intelligent careers. It was also possible to verify the eigenvalues $(>1)$. However, the

\begin{tabular}{lclll}
\hline Constructs & 1 & 2 & 3 & 4 \\
\hline Pressure from technology on career & 0.77 & & & \\
Knowing why & 0.10 & 0.60 & 0.70 & \\
Knowing how & $-0.21^{*}$ & $0.45^{* *}$ & $0.43^{* *}$ & 0.72
\end{tabular}

Notes: The italic results across the diagonal in the matrix represent the confidence ratings. $*_{p}>0.05 ; *^{*} p>0.01$ Source: Prepared by the authors

Traditional and non-traditional career theories 
REGE 25,4

352 assertion with the code "how6" was removed from the analysis because its factorial load and commonalities were lower than the cutoff (0.5).

Next, the study's independent variables were defined and categorized, to test the hypothesis of the influence of variables from the respondent's profile on the pressure from new technologies in their careers, as can be seen in Table VI. In the case of career anchors, we considered only the one with the highest incidence, referred to as the "main career anchor."

In the first model we tested, only the control variables were analyzed, and we found no significant influence on the dependent variable, including the variable of the respondent's main career anchor. However, in the second model, which incorporated the independent variables of intelligent careers, we only found an influence from the information about the department in which the respondent would like to work. Also in model 2 , we found an evolution in the $\mathrm{R}^{2}$ indicator, which demonstrates that the model is better adapted to the data.

These results confirm $H 3$, that the pressures of new technologies on career are more likely to be analyzed with contemporary career models from non-traditional theories than with the models included in traditional theories (Arthur et al., 1999).It is important to remember that the new models support the notion of the development of "career capital" and the need to develop competencies for "intelligent careers," making individuals fully responsible for their professional development, regardless of their inclination in career choices, as was emphasized by Schein $(1990,1996)$.

In the analysis of this study's results, it is worth highlighting the non-influence of the respondent's main career anchor in their perception about the technology, that is, the career orientations represented by the anchors do not imply positive or negative perceptions about new technologies. This is probably related to the scenario in which the concept of anchors arose, as Bravo et al. (2015) pointed out, as well as other concepts associated with traditional career theories. It is important to remember that such theories were created at a social moment that favored organizational careers, as explained by Gunz et al. (2000).

\begin{tabular}{lcc}
\hline Independent variables & $\begin{array}{c}\text { Standardized coefficients }(\beta) \\
\text { Model 1 }\end{array}$ & $\begin{array}{c}\text { Standardized coefficients }(\beta) \\
\text { Model 2 }\end{array}$ \\
\hline Age & -0.049 & -0.017 \\
Gender & -0.069 & -0.059 \\
Employment/unemployment status & -0.143 & -0.160 \\
Position & -0.223 & -0.195 \\
Current department & 0.120 & 0.052 \\
Industry & -0.003 & 0.007 \\
Time at the company & -0.116 & -0.113 \\
Desired department & 0.160 & $0.205^{*}$ \\
Primary career anchor & -0.088 & -0.077 \\
Knowing why & & 0.121 \\
Knowing how & & -0.263 \\
Knowing whom & 0.164 & 0.021 \\
$R^{2}$ & 0.128 & 0.213 \\
$R^{2}$ (adjusted) & 123 & 0.128 \\
$N$ & & 123 \\
Note: $* p>0.05$ & & \\
Source: Prepared by the authors & &
\end{tabular}

Table VI.

Multiple regression analysis results 

pressure from technology on career, we calculated an ANOVA. In the results, only the variable "Position" $(F=2.267, p<0.05)$ showed significant differences in its various levels. The highest averages were found among administrative (2.19) and operational positions (2.11). The lowest averages were found among sales associates (1.28) and managers (1.55). Thus, $H 3$ was confirmed, that is, the pressure of new technologies on the career shows differences depending on the nature of the work that the person performs. Thus, such pressure may be related to the possibility of standardization of certain tasks, according to Trevisan et al. (2016).

These results show that, despite the observation by Frey and Osborne (2013) that even tasks that require greater intellectual effort would be automated, jobs that require more relationship skills, such as sales and management, still seem to produce the feeling of being less threatened by new technologies among youth.

\subsection{Summary of analysis of hypotheses and implications}

H1. Young professionals are concerned about their careers due to the incorporation of new technologies in the organizational context.

Not confirmed. It was found that the lowest mean among the constructs analyzed was the pressure from technology on career:

H2. There is a positive relationship between the perception of the competencies of intelligent careers and the pressure of new technologies.

Partially confirmed. The correlations between the competencies of intelligent careers and the perception of the pressure from technology on career were weak, but significant, whereas the "Knowing How" competency was negatively correlated with the pressure caused by technology:

H3. The pressures of new technologies on careers are more easily analyzed through non-traditional career theories than traditional ones.

Confirmed. There was no significant influence of the anchors on the pressure from technology on career. However, incorporating the competencies of intelligent careers improved the statistical model's fit:

H4. The pressure of the new technologies on the career shows differences depending on the nature of the work that the person performs.

Confirmed. In associating job positions with the pressure from technology on career, administrative and operational positions showed higher averages than sales associate and management positions.

The analyses of the hypotheses lead to reflections that allow us to identify implications for people, companies, and the theoretical field, which we present below.

Among the results, we find the youths' low concern about the pressure from technology on their career. For companies, this can be a major problem, because of the need for training required to implement new technologies. Since youth do not feel the immediate threat of technology, they feel comfortable and are not likely to seek out training of their own volition to meet new job demands. In this sense, Hall et al. (2018) emphasize that a self-directed career as well as personal values, are beneficial both to individuals and to groups and organizations. In this way, awareness about the need for training could lead people to be more self-directed in their search for new forms of work, permeated by technology, in partnership with the organizations where they work. 
REGE 25,4
For people, this same search for training, expressed by the competencies of intelligent careers, especially "Knowing How," leads to higher security with regard to technology. In this way, the new careers continue to stand out in the search for employment options that do not depend so heavily on organizations and on the generation of security based on the competencies of the individuals themselves. The results related to the nature of the work also lead us to believe in the need to plan careers in a way that is more focused on intellectual work that require greater human interaction. In this sense, Callanan et al. (2017) point out that a number of factors now make career decision making somewhat confusing, due to a variety of factors, including changes in the nature of work, increase in on-demand jobs, economic turmoil, evolving technology, and more.

In the theoretical field, we see the relevance of anchors in evaluating current career choices, as highlighted by Bravo et al. (2015). On the other hand, this study's results show the challenge of using this typology to explain the pressures imposed by technology, although other studies show that anchors vary depending on social moment (Veloso et al., 2014). In this sense, Callanan et al. (2017) explain that recessions, technology changes, increased employment restrictions and weakened unions pose challenges for individual career management, making choices somewhat confusing. These authors (Callanan et al., 2017) also raise questions about the relevance and benefit of standard counseling approaches, which emphasize standardized and well-founded methods.

After this discussion of our results, we will present our conclusions from this study below.

\section{Conclusions}

The results shown here confirm that traditional career theories are not enough to explain the impact of new technologies on the labor market, based on automation and the replacement of people by IT systems. On the other hand, the approach to intelligent career competencies can help young professionals cope with these transformations. Even with this finding, there is sparse concern about the topic of technology, as we can observe from the failure to confirm $H 1$.

Nevertheless, one way to cope with the pressure from new technologies on career can be to develop the "Knowing How" competency. In it, learning, whether through formal education or at the workplace itself, tends to reduce the perception of pressure from technology on the career and to produce greater job security.

The confirmation of $H 3$ showed the greater adherence of contemporary career models, included among non-traditional theories, to understand the transformations affecting careers in the Brazilian labor market. Using a professional's inclination for career choices as a benchmark to understand a professional future permeated by new technologies, while important, is not an indicator of awareness of the changes emerging in the current world of work. On the other hand, in an increasingly technological context, the development of competencies and a subsequent investment in career capital grant professionals the means to face and adapt to unforeseeable and volatile scenarios.

$H 4$ indicated that work that was more routine and more easily replaceable in organizations, which appear in operational and administrative positions, create perceptions of more pressure from technology on professionals' careers. At the same time, positions that are more strategic or that demand greater human interaction and that denote increased direct relationship with an organization's results, which are the cases for management and sales levels, produce less pressure from technology and more confidence about the individual's professional future.

As a limitation of this study, we highlight the use of respondents' perceptions about the pressure from new technologies in their careers, which may not represent a real perspective 
of the labor market. In addition, there is a need for future studies to validate the proposed constructs by means of CFA, as well as by replicating the research instruments. Thus, we recommend a qualitative study of the way young professionals face the constant introduction of new technologies in several careers, no longer restricted to hierarchical differences in organizational structure.

\section{References}

Alves, T.L. (2016), "Novas carreiras e o context tecnológico em uma organização com caraterística de Traditional and non-traditional career theories empresa pública", Dissertação (Mestrado em Administração), Faculdades Metropolitanas Unidas, São Paulo, 97pp.

Arthur, M.B. (2014), “The boundaryless career at 20: where do we stand, and where can we go?", Career Development International, Vol. 19 No. 6, pp. 627-640, available at: http://dx.doi.org/10.1108/ CDI-05-2014-0068

Arthur, M.B. and Rousseau, D.M. (1996), "Introduction: the boundaryless career as a new employment principle", in Arthur, M.B. and Rousseau, D.M. (Eds), The Boundaryless Career: A New Employment Principle for A New Organizational Era, Oxford, University Press, New York, NY, pp. 3-20.

Arthur, M.B., Claman, P.H. and DeFillipi, R. (1995), "Intelligent enterprise, intelligent careers", Academy of Management Executive, Vol. 9 No. 4, pp. 7-22.

Arthur, M.B., Hall, D.T. and Lawrence, B.S. (1989), "Generating new directions in career theory: the case for a transdisciplinary approach", in Arthur, M.B., Hall, D.T. and Lawrence, B.S. (Eds), Handbook of Career Theory, Cambrige University Press, pp. 7-25.

Arthur, M.B., Inkson and Pringle, J.K. (1999), The New Careers: Individual Action and Economic Change, Sage Publications, London.

Autor, D.H. and Price, B. (2013), “The changing Ttsk composition of the US labor market”, An update of Autor, Levy, and Murnane (2003), MIT Paper, June 21, available at: http://economics.mit.edu/ les/9758 (accessed April 10, 2015).

Barley, S.R. (1989), "Careers, identities, and institutions: the legacy of the Chicago School of sociology", in Arthur, M.B., Hall, D.T. and Lawrence, B.S. (Eds), Handbook of Career Theory, Cambridge University Press, New York, NY, pp. 41-65.

Barley, S.R, Bechly, A.B. and Milliken, F.J. (2017), "The changing nature of work lives in the 21st century", Academy of Management Discoveries, Vol. 3 No. 2, pp. 111-115, available at: https:/ /doi.org/10. 5465/amd.2017.0034

Bell, N.E. and Staw, B.M. (1989), "People as sculptors versus sculpture: the roles of personality and personal control in organizations", in Arthur, M.B., Hall, D.T. and Lawrence, B.S. (Eds), Handbook of Career Theory, Cambridge University Press, New York, NY, pp. 232-251.

Boh, W.F., Slaughter, S. and Ang, S. (2001), "Is information technology a 'boudaryless' profession? A sequence analysis of the career histories of it professionals from 1979-1998”, Academy of Management Proceedings, pp. A1-A6.

Bravo, J., Seibert, S.E., Kraimer, M.L., Wayne, S.J. and Liden, R.C. (2015), "Measuring orientations in the era of the boudaryless career", Journal of Career Assessment, Vol. 25 No. 3, pp. 505-525, doi: $10.1177 / 1069072715616107$.

Callanan, G.A., Perri, D.F. and Tmkowicz, S.M. (2017), "Career management in uncertain times: challenges and opportunities", The Career Development Quarterly, December, Vol. 65 No. 4, pp. 353-365, doi: $10.1002 /$ cdq.12113.

Dalton, G. and Thompson, P. (1977), "The four stages of professional careers”, Organizational Dynamics, Vol. 6 No. 1, pp. 19-42.

Frey, C.B. and Osborne, M.A. (2013), "The future of employment: how susceptible are jobs to computadorisation? Oxford University Engineering Sciences Department and the Oxford Martin", Programme on the Impacts of Future Technology Paper, September 17, available at: www.ox fordmartin.ox.ac.uk/downloads/academic/The_Future_of_Employment.pdf (accessed April 20, 2015). 
REGE 25,4

Gomes, D.F.N., Veloso, E.F.R., Silva, R.C. and Trevisan, L.N. (2013), "Contribuição das Âncoras de Carreira para Entender Diferenças e Similaridades na Geração Y”, Revista de Ciências Humanas, Vol. 47 No. 1, pp. 152-171.

Guan, Y., Arthur, M.B., Khapova, N.K., Hall, R.J. and Lord, R.G. (2017), "Career boundarylessness and career success: a review, integration and guide to future research", Journal of Vocational Behavior (in press), doi: 10.1016/j.jvb.2018.05.013.

Gunz, H., Evans, M. and Jalland, M. (2000), "Career boundaries in a 'boundaryless' world”, in Peirpel, M.A., Arthur, M.B., Gofee, R. and Morris, T. (Eds), Career Frontiers: New Conceptions of Working Lives, Oxford University Press, Oxford, pp. 1-45.

Haeger, D.L. and Lingham, T. (2014), "A trend toward work life fusion: a multi-generational shift in technology use at work", Technological Forecasting and Social Change, Vol. 89 No. 9, pp. 316-325.

Hair, Jr, Black, W.C., Babin, B.J., Anderson, R.E. and Tatham, R.L. (2009), Análise multivariada de dados, 6th ed., Bookman, Porto Alegre.

Hall, D.T. (1976), Career in Organizations, Goodyear, Pacific Palisades, CA.

Hall, D.T. (1986), "An overview of current career development theory”, in Hall, D. (Ed.), Associates, Career Development in Organizations, Jossey-Bass Publishers, San Francisco, CA, pp. 1-20.

Hall, D.T. (1996), Preface. Hall, D. \& Associates. The Career is Dead - Long Live the Career, Jossey-Bass Publishers, San Francisco, CA.

Hall, D.T. (2002), Careers in And Out of Organizations, Sage Publications, London.

Hall, D.T., Yip, J. and Doiron, K. (2018), "Protean career at work: self-direction and values orientation in psychological success", Annual Review of Organizational Psychology and Organizzational Behavior, Vol. 5 No. 6, pp. 1-6, available at: https://doi.org/10.1146/annurev-orgpsych032117-104631

Khapova, S.N., Arthur, M.B. and Wilderom, C.P.M. (2007), "The subjective career in the knowledge economy", in Gunz, H. and Peirperl, M. (Eds), Handbook of Career Studies, Sage, Thousand Oaks, CA, pp. 114-130.

Kostal, J.W. and Wiernik, B.M. (2017), "A meta-analytic investigation of demographic differences in protean, boundaryless, and proactive career orientations", Career Development International, Vol. 22 No. 5, pp. 520-545, available at: https://doi.org/10.1108/ CDI-08-2017-0139

Quinn, J.B. (1992), Inteligent Enterprise, Free-press, New York, NY.

Schein, E.H. (1978), Career Dynamics: Matching Individual and Organizational Needs, Addison-Wesley, Reading, MA.

Schein, E.H. (1990), Career Anchors: Discovering Your Real Values, Pfeifer \& Company, University Associates, Inc., San Diego, CA.

Schein, E.H. (1996), Identidade profissional: como ajustar suas inclinações a suas opções de trabalho, Nobel, São Paulo.

Silva, R.C., Trevisan, L.N., Veloso, E.F.R. and Dutra, J.S. (2016), "Career anchors and values from different career management perspectives", Revista Brasileira de Gestão de Negócios, Vol. 18 No. 59 , pp. $145-162$.

Trevisan, L.N. (2014), "Realidade virtual versus mundo corporativo", Revista da ESPM, set./out.

Trevisan, L.N., Veloso, E.F.R., Silva, R.C. and Dutra, J.S. (2016), "Âncoras de carreira e tecnologia na percepção sobre estresse no ambiente de trabalho”, Vol. 12 No. 24, pp. 65-90.

Van Maanen, J. (1977), Organizational Careers: Some New Perspectives, Wiley, New York, NY.

Veloso, E.F.R. (2009), "Carreiras sem fronteiras na gestão pessoal da transição profissional: um estudo com ex-funcionários de uma instituição com características de empresa pública", Tese (Doutorado em Administração) Faculdade de Economia, Administração e Contabilidade da Universidade de São Paulo, São Paulo, 513pp. 
Veloso, E.F.R. (2012), Carreiras sem fronteiras e transição profissional no Brasil: desafios e Traditional and oportunidades para pessoas e organizações, Atlas, São Paulo, 168pp.

Veloso, E.F.R., Silva, R.C. and Dutra, J.S. (2012), "Diferentes gerações e percepções sobre carreiras inteligentes e crescimento profissional nas organizações", Revista Brasileira de Orientação non-traditional Profissional-ABOP, Vol. 13 No. 2, pp. 197-207.

Veloso, E.F.R., Silva, R.C., Gomes, D.F.N., Trevisan, L.N. and Dutra, J.S. (2014), "Momento Social, Valores e Expectativas: Como as Mudanças Econômicas Influenciam a Visão dos Jovens sobre o Trabalho?", Revista Organizações em Contexto, Vol. 10 No. 19, pp. 279-305.

Corresponding author

Rodrigo Cunha da Silva can be contacted at: rdgcdasilva@gmail.com

For instructions on how to order reprints of this article, please visit our website: 